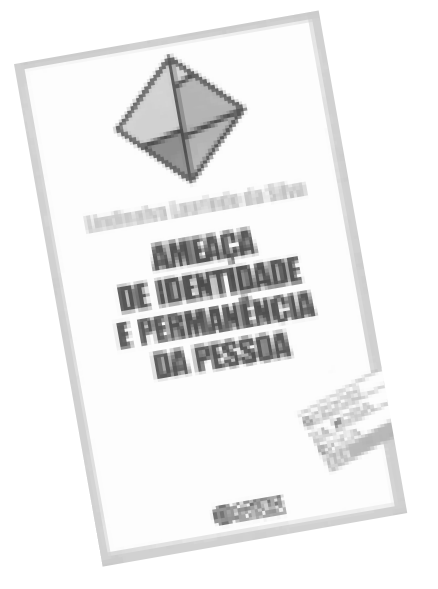

\title{
livros
}

\section{Ameaça de identidade e permanência da pessoa}

LAURINDO DA SILVA, L. Trad. Rodnei A. Nascimento. São Paulo: Cortez, 2004. (Coleção Questões da nossa época, v.113). 120p.

Em boa hora chega ao Brasil, lançado na última Bienal do Livro, em São Paulo, em abril deste ano, esse trabalho de Lindinalva Laurindo da Silva, parte de sua tese de doutorado, defendida na École des Hautes Études em Sciences Sociales-Paris e publicada pela editora Harmattan, em $1999^{1}$. Com certeza, a leitura desse texto será de grande relevância para os estudiosos da Aids, assim como para os cientistas sociais que se questionam sobre as possibilidades de articular as abordagens das representações sociais e das ações específicas das pessoas, quando se trata de analisar uma doença grave e mortal.

A base do estudo é uma investigação empírica sociológica, realizada em 1988, junto a quarenta doentes de Aids em fase avançada, homossexuais e bissexuais masculinos, internados em hospital-dia do Centro de Referência e Treinamento de DST/ Aids (CRT) da Secretaria de Saúde do Estado de São Paulo.

O texto, desenvolvido de forma extremamente didática, inicia-se com uma breve introdução, na qual a autora reafirma a atualidade da problemática da Aids, pois apesar dos progressos em relação ao tratamento dessa doença, ocorridos após a realização da investigação, não se pode esquecer que as pessoas continuam morrendo da doença ainda que em menor número, e são bastante significativos os efeitos colaterais do longo e duro tratamento. Por isso, o estudo não se inscreve na história da epidemia, pois

$$
\begin{aligned}
& \text { na confrontação com qualquer doença } \\
& \text { grave e crônica, a pessoa deve ordenar } \\
& \text { todos os problemas que a afligem: } \\
& \text { tratamento, manutenção da vida } \\
& \text { material, questões de conotação moral, } \\
& \text { a perspectiva de morte contida na } \\
& \text { doença e o vínculo com os outros e } \\
& \text { consigo mesmo. (p.11) }
\end{aligned}
$$

Em seguida, no capítulo I, Da representação à ação: as doenças e os doentes como objetos da sociologia, a autora apresenta o quadro teórico que fundamenta sua análise. Trata-se de referencial no qual as representações sociais mais gerais em relação à doença são articuladas às ações singulares do doente, enquanto pessoa, que (re) constrói sua identidade perante a doença, $e$, dessa forma, pode atuar na sociedade que a cerca. Para a primeira dimensão, a autora apóia-se, sobretudo, nas contribuições de Claudine Herzlich; em relação à segunda, em Paul Ricoeur, por meio de sua reflexão em $O$ si mesmo como um outro, onde o autor define as quatro dimensões da noção de 
pessoa: a linguagem (o homem que fala), a ação (o homem que age/sofre), a capacidade de relatar (o homem narrador de sua experiência de vida) e a vida ética (o homem responsável) (p.27). As dimensões da ação $e$ da ética são articuladas aos dois modelos básicos de ação analisados por Luc Boltanski $e$ Laurent Thévenot: as ações baseadas nas idéias de justificação e competência $e$ a ação baseada no amor.

No segundo capítulo, $A$ estabilidade da identidade pelo compartilhamento de uma história comum, após discutir sobre o sentido da condição homossexual, quando se pensa na questão da identidade da pessoa, a autora aborda os relatos dos entrevistados a respeito do seu passado sexual quando se percebem como homossexuais, com toda problemática que isso significa, e de seu presente com a Aids. Em ambas as situações, naquele momento fortemente relacionadas, a autora percebe que, muitas vezes, a permanência da identidade é dada, sobretudo, pelo compartilhamento das experiências de cada um com os outros em condição semelhante. Ao final do capítulo, a autora enfatiza a significação do relato, pois

o rearranjo de si encontra coerência inicialmente na narração. Pelo envolvimento no discurso, a pessoa é levada a testemunhar seu passado e seu presente, assegurando, na entrevista, uma continuidade identitária perante as mudanças sobrevindas com a doença. (p.75)

No capítulo III, $A$ construção da incerteza e a manutenção da identidade, o leitor terá contato com outros relatos dos entrevistados referindo suas vidas após a Aids. Nessas narrativas aparecem os sentimentos experimentados pelos doentes: da dúvida com relação ao diagnóstico, passando pela revolta ao confirmá-lo, e à aceitação da doença, às vezes alcançada devido à emergência de um estado espiritual, outras vezes voltando-se para si mesmos na busca de respostas para a situação. Tal conformação ao estado de doente expressa-se bem na fala de um entrevistado que chegou a afirmar:
Acho que a Aids, é horrível dizer, é positiva. (...) Talvez porque ela te fragilize muito,você se torna mais aberto a esses sentimentos, a essa benevolência. (...) Essas circunstâncias levam a uma meditação muito maior. Levam a refletir sobre a vida e a morte, sobre a existência, seu princípio e seu fim. (p.108)

Ou seja, trata-se da certeza de que a prova última que resta ao doente é sua relação com a morte. Como conclui a autora: nessa prova, é a coerência que permite ao doente ir em direção ao mais profundo do seu ser. Isso porque, a partir daí,
a coerência da pessoa pode então ser reportada à seguinte questão: o que resta da pessoa quando os seres mobilizáveis são rarefeitos? Resta ainda a pessoa. O que resta da pessoa quando ela perdeu os pontos de referência da vida cotidiana? Resta o si profundo, essa subsistência que encontra nela mesma o seu apoio e a manutenção do laço com o outro. (p.113) grifos da autora da resenha.

Solange L'Abbate Departamento de Medicina Preventiva e Social Faculdade de Ciências Médicas, Universidade de Campinas, Unicamp <slabbate@fcm.unicamp.br>

PALAVRAS-CHAVE: Aids; aspectos psicológicos; aspectos sociais; relatos de vida.

KEY WORDS: Aids; psychological tests; reports of life. PALABRAS CLAVE: Aids, aspectos psicologicos; informe de vida.

Recebido para publicação em 07/10/04. Aprovado para publicação em 22/10/04. 